\title{
SPIRITUAL HEALTH AS AN INTEGRAL COMPONENT OF HUMAN WELLBEING
}

\author{
JUŠKIENĖ Vaineta \\ Klaipèda University, Klaipèda, Lithuania \\ Klaipeda State University of Applied Sciences, Klaipeda, Lithuania
}

\begin{abstract}
The aim of this study is to actualize personal spiritual health as a fundamental component of human wellbeing. In Lithuania research on spiritual health has not been developed yet as a result of political thinking in the post Soviet legacy which sought to eliminate the factor of spirituality from scientific context, and also due to recent socio-economic trends to over-emphasize the material dimension of personal welfare. Christian anthropology, which has laid foundations for Western European humanist heritage, emphasizes the physical and spiritual components of integrity of the human person and declares the importance of personal spiritual harmony for achievement of fullness of life. While employing analysis of scientific literature and Church documents, this study sought to highlight the basic criteria of personal spiritual health and scientific empirical approaches to establish the importance of spiritual health in the context of comprehensive human wellbeing. The study reveals that an essential component of the concept of spiritual health is relationship. Spiritual health is an important component of human wellbeing enabling the person to cope with personal existential crises in various aspects of human life: stressful situations, illness or presence of death. Research confirms that spiritual health correlates with and is an important positive factor in the overall process of human healing. It may be assumed that actualization and improvement of spiritual health can significantly contribute to the processes of coping with social pathologies present in the modern society.
\end{abstract}

Keywords: Christianity; Health; Spirituality; Transcendentality; Wellbeing.

\section{Background}

Issues of wellbeing have always been topical on both theoretical and empirical levels. Human wellbeing has been analysed by representatives of economics and health sciences as well as spiritual thinkers and theologians. Perception of wellbeing or fullness of life is dynamic and has therefore caused controversial discussions. Comprehensive economic welfare is usually perceived as an essential indicator and measure of wellbeing in the modern society. Nowadays there is an emphasis on cognitive, technological and socioeconomic advancement, which can add a clear and measured value to the wellbeing of a modern-day person. Although these factors are, without doubt, important components of wellbeing, they tend to ignore non-material aspects of human nature and spiritual wellbeing. It is evident that the above mentioned constituents and advancement cannot guarantee a comprehensive human wellbeing. Present day society 
clearly suffers from personal and social crises as well as from spiritual pathologies such as criminogenic situation, suicide and family crises. Therefore, there is a need for a holistic approach, which would integrate both metaphysical and physical aspects into the context of human wellbeing. As sharers of the heritage of Western culture, we could refer to Christian anthropology, which states that a person is created for the unity of two essential components - physical and spiritual (Catechism of the Catholic Church, 2012). The latter raises questions of existential nature: is human potential alone, without the transcendental level, sufficient for achieving a complete quality of life? Spiritual health is perceived here as an essential component of human wellbeing.

Secular scientific researches approach issues of human wellbeing from a variety of perspectives. Spiritual role of wellbeing has been analysed in this context both from personal and social points of view (Fisher, $1998,2002,2008,2009,2010)$, spiritual health is commonly studied as a component of the overall human health (Hawks, 1994, 2004, 2007; Dhar, 2011; Koenig, 2012) and the impact of personal relation with God on spiritual health has also been highlighted (Fischer, 2012, 2013). No significant research of this nature has been developed in Lithuania yet. Features of spiritual health have been briefly analysed on a theoretical level (Paijanskaitè, 2009; Juškienė \& Piktuižytė, 2014). This topic has been indirectly touched upon in wellness research (Pranckevičienė et al., 2012; Valiulienè, 2013). Non-material level of human wellbeing is frequently analysed from the point of view of normal psychological state although this context usually fails to identify an aspect of spiritual health. This gap in Lithuania might have been caused by a legacy of post-soviet thinking and popular past trends that spirituality cannot and should not be researched scientifically (Miler \& Thoresen, 2003). However recently, these attitudes have been clearly changing. There has appeared a broader understanding of human beings as spiritual individuals without diminishing their dignity and perceiving the transcendental basis for their existence. This research employs analysis and interpretation of scientific literature and official church documents to search for criteria of spiritual health and possible empirical approaches to its evaluation. A scientific question is raised: On what aspects can spiritual health be approached as an integral component of human wellbeing? While analysing this issue the object of the research - spiritual health in the context of human wellbeing - has been chosen. The aim of the research is to reveal the features of the expression of spiritual health and to actualise its role in human wellbeing.

\section{Aspects of the Concept of Human Wellbeing in Modern Society}

Today the concept of wellbeing is very popular and is diversely used both in scientific work and in different documents where it is usually associated with the quality of human life, physical and mental health and material welfare. Wellbeing encompasses a lot of aspects of human life. Today there is still an on-going discussion between various strains of this concept: wellbeing, welfare, satisfaction with life, a happy life, etc. (Krutulienè, 2012). According to scientists, two main value-based orientations in this context are satisfaction with one's life in general and the feeling of happiness (Milaševičiūte et al., 2006). Most sociologists and 
economists identify these two basic evaluations and assume them to render the same result whereas even in the previous century other scientists (Andrews \& McKennel, 1980) noticed that satisfaction with life and the feeling of happiness produce different outcomes: satisfaction with life is based on material status while the feeling of happiness has a spiritual foundation.

With a retrospective insight into the scientific search for the concept of wellbeing it is worth remembering that one of the first definers of wellbeing was a representative of health sciences Dunn (1959) whose work emphasised the importance of spiritual dimension on human wellbeing and highlighted the holistic approach stating that a high standard of wellbeing is unachievable through a fragmental perception: "Harmony will result when the fact is faced that man is a physical, mental, and spiritual unity - a unity which is constantly undergoing a process of growth and adjustment within a continually changing physical, biological, social, and cultural environment.“ (Dunn, 1959, p. 789). Thus, the dimension of spirituality was perceived as topical and significant in the world of science. It is worth mentioning that at that time Lithuania was undergoing an especially active period of sovietisation when radically opposite ideas, aiming to brutally eliminate a metaphysical dimension of anthropology both from science and from the sphere of social life, prevailed in our country. The transcendental level of human existence was declared an anti-scientific superstition which was to be destroyed as damaging the mind of soviet people. The concept of wellbeing was based on ideology of scientific atheism and perspective of communist future. This aggressively pursued five-decade-long materialistic policy of pseudo-wellbeing manifested itself in reality as de-spirituality of human personality and culture of deficit. This produced obvious consequences that might have caused the present trend to overemphasize the material aspect of human wellbeing (Spinter Research, 2012).

Two main groups of criteria defining the wellbeing of a modern person, i.e. health and material welfare based on the culture of consumption, dominate in the analysis of present day considerations on the topic of wellbeing. Affected by ideas of consumerism, the present concept of wellbeing tends to resemble financial welfare with subsequent comfort and pleasure. Other fundamental values lose their significance in this perspective and the context of an integral human development is damaged. The danger of the trend to overemphasise material welfare presents itself as a straightforward pursuit of higher quality of life unexceptionally leading towards practical materialism with its individualistic, utilitarian and hedonistic consequences (Milaševičiūtè et al., 2006). There is an underlying paradox in the fact that while material conditions of life improve, social pathologies in a society do not disappear. This problem is evident both in the devastating rate of suicide and in other incomprehensible forms such as infanticide. It is obvious that dealing with problems greatly depends on our approach to a person and his/her wellbeing. 
DOI: 10.1515/arhss-2016-0002

Applied Research In Health And Social Sciences: Interface And Interaction, Vol. 13, No. 1, 2016

\section{Spiritual Health as a Measure of Human Existence}

An insight into human wellbeing through a perspective of health reveals that a modern integrated paradigm of health prevails in scientific literature. Health is therefore defined as a holistic, multidimensional phenomenon encompassing physical, psychical, emotional, social and spiritual components and to be fully realised only when all these health components are in harmony. World Health Organisation (WHO) provides a definition of health as a comprehensive physical, psychical and social wellbeing and not only absence of disease or disability (World Health Organization, 1946). Although a spiritual health component is not officially included in the health definition by WHO, spiritual level of health is recognised in some projects of health development. The present Law of the Health System (1994) of the Republic of Lithuania also indicates that "health is a physical, spiritual and social wellbeing of a person and society." A comprehensive approach towards human health is not limited by diagnosing and treating diseases, but it places equal importance on personal psychical, social and spiritual wellbeing in the sphere of human health and welfare. Thus, all components of health are dynamic and the state of health is not perceived as a static ultimate aim, but rather as an on-going process or a state to be achieved and retained (Hawks, 2004; Šveikauskas, 2008). This is a definition of a positive health theory, which defines health not only as an absence of physical illness or disorder, but also as a state of wellbeing, capability and ability (Jakušovaitè, 2011). Due to complexity and multidimensionalism of the spiritual human component there is no generally accepted concept of spiritual health, but the newest researches indicate a movement towards a more common paradigm of describing spiritual health (Juškienė \& Piktuižytė, 2014).

Analysis of research studies performed in the context of spiritual health highlights the essential aspects of defining spiritual health. According to professor of health education Hawks (1994), it is possible to state that spiritual health is a high level of faith, hope and commitment which is caused by a clearly defined worldview or a system of faith providing with the meaning of life and leading a person towards self-fulfilment through a firm adherence to moral values and integrating the relation with oneself, others and a higher force. The research by Hawks (1994) proves that person-oriented constructs, such as individualism and orientation towards success or personal freedom, have a destructive impact on spiritual health. Ellison defines spiritual wellbeing as a constant and dynamic self-reflection of one's spiritual health and maturity (ref. Steinmann, 2010). Professor of the National Institute of Health and Family Welfare in India Dhar (2011) considers spiritual health to be a state, which expresses itself through an individual ability to live in such a way, which leads towards realising one's inner potential, meaning and purpose of life and provides with an internal source of happiness. According to Steinmann (2010), the spiritual component of wellbeing is an existential component experienced by each person - healthy or unwell. Spiritual health defines the management strategy of personal life which indicates the way to experience effectively different aspects of human existence, for example how to behave in the face of stressful situations, illness or death. 
DOI: $10.1515 /$ arhss-2016-0002

Applied Research In Health And Social Sciences: Interface And Interaction, Vol. 13, No. 1, 2016

\section{Spiritual Measure of Human Wellbeing from a Christian Perspective}

Dignity of human personality and importance of spiritual health are emphasised by Christian anthropology. Anthropological attitude is essential in the concept of wellbeing because only when we understand what a person is we can consider what makes the foundation of human wellbeing. We must accept the fact that Christian teaching, which praised the man as Imago Dei encompassing in his nature the spiritual and material systems, laid the basic foundation for the concepts of human dignity and spirituality in the Western culture. The man possesses an exceptional place in the whole creation. The concept of "spirit" (Hebr. Ruach, Lat. Spiritus) is related in this teaching to the basis of human life. The Christian Holy Scripture perceives the man as a creation of God, whom the Creator entrusted with a spiritual nature revealing the relation between God and man which is impossible to test by empirical methods. Spirit and matter within a person are not two inter-connected forms of nature, but, being united, they make a single nature (Catechism of the Catholic Church, 2012). Christianity puts an emphasis on a direct link between the human spirit and the divine Person, the unity with whom perfects the human personality (Špidlik, 2007).

From the perspective of wellbeing, theology states that all creation is made good although it is not yet perfect and therefore it is driven by God towards final perfection. Christianity reveals the meaning of existence, purpose and the real vocation of the man as God's creation. The spiritual human nature indicates the supernatural human vocation. The man was created to serve God in love, to follow a path of personal perfection and to sanctify himself while resembling Christ, to mature for eternity while carrying out the divine plan of redemption and thus to reach completeness in God (Catechism of the Catholic Church, 2012). Christian self-realisation of a person takes place and is possible with the assistance of God's grace while the person is changed and spiritualised in the power of the Holy Spirit (Špidlik, 2007).

According to Christian anthropology, human peace and completeness is possible only in unity with God and, therefore, spiritual health can be expressed as the quality of the relation with God. Pope John Paul II emphasised the metaphysical discourse of human wellbeing on numerous occasions: "Man is called to a fullness of life that far exceeds the dimensions of his earthly existence, because it consists in sharing the very life of God" (John Paul II, 1995, No 2). Christian teaching reveals consequences of God's elimination from the life of modern person. Loss of the relation with God and ignoring the spiritual human nature has a destructive impact on human self-perception and acknowledgment of human dignity and value of life. Unlimited freedom in a godless world becomes a source of internal anxiety and foundation of materialism and alienation, which form a consuming, controlling and dominating individual. These consequences are clearly evident in the present day society.

Pope Emeritus Benedict XVI also touches upon the topic of human wellbeing in his encyclical letter Caritas in veritate. He puts an emphasis on the holistic human development while actualising necessity for spiritual perfection in the world, where secularism and pragmatism are increasingly spreading. The encyclical letter states that God's love calls to leave everything limited and temporary and encourages to 
continue searching for the universal good (Benedict XVI, 2009). An authentic human perfection and development requires nurturing of spiritual life, faith in the Divine and community with Christ, overstepping of egoism, justice and peace. Holistic human development is possible only when spiritual human nature is developed in relation with God.

While discussing a conflicting human state in the present day world in his encyclical letter Laudato si, Pope Francis states that "human life is grounded in three fundamental and closely intertwined relationships: with God, with our neighbour and with the earth itself. According to the Bible, these three vital relationships

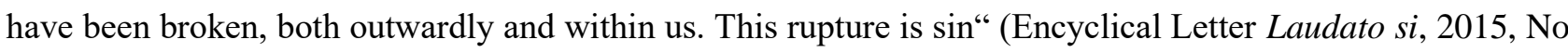
66). It is the sin which allows for occurrence and development of spiritual pathologies. Reconstruction of this disharmony is a crucial prerequisite for spiritual health.

Truths of religious faith provide the faithful with answers to essential questions about the construction of the world, the human place in it, the meaning of existence and also indicate how to seek for the fullness of being, i.e. wellbeing. The system of Christian values is based on the Decalogue and its breach means breaking the relationship with God and destroying spiritual human harmony. The latter presents itself in the form of different spiritual ailments. Psychiatrist Peck reveals the connection between God's will and psychical disorders. He believes that personal departure from God's will is an essential cause of psychical disorders (Peck, 2009). As breach of moral laws becomes a norm in a society, people distance themselves from God and from the fulfilment of their vocation. From the point of view of Christian theology, a broken transcendental relation can be restored through repentance and conversion. This spiritual resurrection frees people, heals them and recreates the divine image within them. At the same time self-confidence and human dignity are regained while the real identity is re-discovered (John Paul II, 1995). Thus human internal desires transform into beliefs that do not conflict with moral values and conscience. This is a fundamental prerequisite for spiritual health. Christian anthropology enables to view the human person as a creation of God that transcends the level of the nature and possesses a divine background and an eternal purpose. Therefore, the physical level is insufficient for the achievement of human wellbeing. Spirituality is a fundamental constituent of human personality. Spiritual health can be restored and maintained when two poles - human and divine - are in action. From Christian perspective this is perceived as a foundation of human wellbeing.

\section{Aspects of Expression of Spiritual Health in the Context of Research on Human Wellbeing}

Spiritual health has been analysed in scientific researches from different perspectives. Its expression is studied both separately and in connection to the basis of personal religious faith. Dhar, Chaturvedi and Nandan composed a valid scale of measuring spiritual health without a religious or cultural bias. It is based 
on a spiritual health model which highlights three essential levels of spiritual health (Dhar et al., 2011). The latter model defines spiritual health as a state of health which can be expressed on the following levels:

1. personal advancement (a state of becoming through the use of internal potential);

2. self-actualisation (a high level of self-perception as well as a deeper understanding of the meaning of life and the reaction it forms towards the environment, people and events);

3. transcendence (a state of internal happiness, a source that inspires the feeling of universal community and love).

Empirical studies in this context prove a direct link between the levels of spiritual and physical health: a higher level of spiritual health of seriously ill people (e.g. oncological patients) is viewed as a lenitive factor and some in-use spiritual aspects, e.g. forgiveness, are said to mobilise the immune system (Dhar et al., 2011).

Work by Fisher has had an enormous input into identification and actualisation of spiritual wellbeing. On the basis of his theoretical and empirical research he developed the theory of the "model of spiritual wellbeing" and composed "SHALOM" - an instrument to measure spiritual health, both of which received wide acknowledgement in the world of science and practical application in further researches (Fisher, 1998; 2009; 2010 et al.). Fisher states that spiritual health is connected not only to the sphere of mind, reasoning and emotions. Its nature is relative. The theory of four domains of spiritual wellbeing defines the state of spiritual health through an assessment of quality of four types of relations in a person's life. The following domains are distinguished:

- Personal level is expressed in the relation with inner I (integration of the purpose, meaning of life and the system of values, an increasing self-perception of personal identity, self-reliance and peace);

- Communal level where spiritual health is defined by the quality and depth of interpersonal relations with others, links with morale, religion and culture (love, justice, hope and faith in humanity);

- Environmental level expresses the quality of relation with the environment (concern about the nature, admiration of the environment or experience of unity with the natural world);

- Transcendental level defines personal relation with the transcendental "Other"/God or superhuman force (expressed through faith, worship and glorification) (Fisher, 2009).

Spiritual harmony or disharmony in the relations of these levels is assessed in terms of undergoing the relationship between a personal ideal and factual experiences. According to Fisher, disharmony or lack of any of these links prevents the person from experiencing the feeling of spiritual completeness. This state causes spiritual diseases. The quality of relations is dynamic and they correlate on all of the above mentioned levels. Different rises and falls in life have a significant influence on personal spiritual health.

It is worth stating that the connection between the first three domains (relations with oneself, environment and others) and spiritual health are almost commonly accepted in the world of science. However, the level of the relation with God (transcendental) is treated ambiguously in the model of spiritual health. There are 
efforts to develop the concept of spiritual health from the perspective of such a theory where religion and spirituality are treated as separate phenomena and a secular character of spirituality is frequently emphasised (Hawks, 1994; Dhar et al., 2011). Fisher addressed this issue in one of his scientific researches in order to ascertain the role of the level of the relation with God in personal spiritual wellbeing. The obtained empirical data revealed that the transcendental connection with God was the most important factor for the respondents' spiritual health (Fisher, 2010). Analogical data was also obtained in another research performed by a group of scientists where spiritual health of teachers of primary schools in England was examined. The research revealed a close connection between personal religious practices (attending a church, a private prayer) and a positive influence on spiritual health on the level of the transcendental relation. Fisher states that God/Transcendental Other possesses a potential to improve the evaluations of spiritual health not only on the transcendental level, but also in relationships on the personal, communal and environmental levels. Thus, faith and personal relation with God have positive effect on the whole of personal wellbeing. Scientists also state that spiritual health does not correlate with social conformism and does not reflect personal emotional lability or stability. Higher evaluations of spiritual health apply to people of senior age who practice religious beliefs (Fisher, 2010). There is a positive correlation between personal spiritual health and personal practical relation with God.

Spiritual health has an important connection with a comprehensive process of personal healing (Steinmann, 2010). Analyses of wide-scope empirical researches show that religious/spiritual measure is an essential factor not only in treating diseases, but also in overcoming stressful changes of life (Koenig, 2012). This proves that spiritual health has to be approached as an integral constituent of comprehensive human wellbeing. It is possible to state that personal internalised world-view constitutes for a person a deep integrating component. People with serious physical ailments, but at the same time possessing a high level of spiritual health, are able to easier overcome different somatic disabilities and life crises while finding the meaning of life from a pragmatic point of view in absolutely unfavourable life conditions. It is possible to assume that in this context an adequate physical welfare is not as important as a deeper perception of the meaning of life and a general acknowledgement of the value of oneself as a creation of God.

\section{Conclusions}

A variety of factors influence the quality of human life. Nowadays human welfare is frequently perceived as a political and economic ideal which not only satisfies the basic societal needs, but also ensures the desired welfare: economic prosperity, social security, sufficient healthcare and so on. However, preservation of unimpaired dignity of human self in this context requires attention to the dimension of spiritual wellbeing.

From a Christian perspective, spiritual health is determined by the quality of personal relation with God and the subsequent moral responsibility. The Creator endowed the human being with a spiritual principle 
DOI: $10.1515 /$ arhss-2016-0002

Applied Research In Health And Social Sciences: Interface And Interaction, Vol. 13, No. 1, 2016

which constitutes an integral part of personal wellbeing. Meaningful worldview and perception of the purpose of life both from the present day and eschatological perspectives play an important role in spiritual human health. This ensures the development of positive internal relationship with oneself, the others and God, which provides for a restitution of sin-destructed harmony as an essential prerequisite for spiritual wellbeing.

Human personality is characterised by keeping relationships and, therefore, both from religious and secular perspectives expression of spiritual health is assessed as relation. Analysis of scientific researches reveals that spiritual wellbeing is a dynamic state manifesting itself through relations with oneself, the others, the environment and God. Analysed empirical data prove the importance of transcendental relationship with God on the personal spiritual wellbeing and reveal the existing link between the levels of spiritual and physical health. It is possible to assume that actualisation of spiritual health and its improvement on the levels of communal and environmental relations could significantly contribute to processes of dealing with social-moral pathologies afflicting the modern society. From these perspectives it is possible to state that personal spiritual wellbeing is an integral constituent of human wellbeing.

\section{References}

Andrews, F. M. \& McKennel, A. C. (1980). Measures of Self-reported Well-being: Their Affective, Cognitive and Other Components. Social Indicators Research, 8(2), 127-155.

Dhar, N., Chaturvedi, S. K., \& Nandan, D. (2011). Spiritual health scale 2011: defining and measuring $4^{\text {th }}$ dimension of health. Indian Journal of Community Medicine, 36(4), 275-282. Available at: http://www.ijcm.org.in/text.asp?2011/36/4/275/91329 (Accessed on 30/06/2016).

Dunn, H. L. (1959). High-Level Wellness for man and society. American Journal of Public Health, 49(6), 786-792.

Encyclical Letter LAUDATO SI' of the Holy Father Francis on Care for our Common Home (2015). Available at: http://w2.vatican.va/content/francesco/en/encyclicals/documents/papa-francesco_20150524_enciclica-laudatosi.html (Accessed on 09/06/2016).

Fisher, J. W. (2009) Understanding and assessing spiritual health. International Handbook of Education for Spirituality, Care and Well-being. Available at: https://www.researchgate.net/publication/226231017_Understanding_and_Assessing_Spiritual_Health (Accessed on 23/06/2016).

Fisher, J. W. (1998). Spiritual Health: It's Nature and Pplace in School Curriculum. Doctoral dissertation. Melbourne: University of Melbourne. Available at: https://minervaaccess.unimelb.edu.au/bitstream/handle/11343/39206/67162_00002994_01_Fisher.pdf?sequence=1 (Accessedd on 30/06/2016).

Fisher, J. W.(2010). Development and application of a spiritual well-being questionnaire called SHALOM. Religions, 1(1), 105-121. Available at www.mdpi.com/2077-1444/1/1/105/pdf (Accessed on 23/06/2016).

Fisher, J. W., Francis, L. J. \& Johnson, P. (2002). The personal and social correlates of spiritual well-being among primary school teachers. Pastoral Psychology, 51 (1), 3-11. Available at: 
DOI: 10.1515/arhss-2016-0002

Applied Research In Health And Social Sciences: Interface And Interaction, Vol. 13, No. 1, 2016 http://download.springer.com/static/pdf/420/art\%253A10.1023\%252FA\%253A1019738223072.pdf?originUrl=h ttp\%3A\%2F\%2Flink.springer.com\%2Farticle\%2F10.1023\%2FA\%3A10197382 (Accessed on 23/06/2016).

Hawks, S. R. (1994). Spiritual health: definition and theory. Wellness Perspectives, 10(4), 3. Available at: http://www.mesacc.edu/ barmd97231/SpiritualHealth.html (Accessed on 04/07/2016).

Hawks, S. R. (2004). Spiritual wellness, holistic health, and the practice of health education. American Journal of Health Education, 35 (1), 11-16.

Jakušovaitè, I. (2011). Medicinos filosofija. Kaunas: Kauno medicinos universiteto leidykla.

Juškienė, V., \& Piktuižytè, I. (2014). Dvasinès sveikatos samprata ir jos bruožai. Tiltai, 45, 30-49.

Kataliku Bažnyčios Katekizmas. (2012). Vilnius: Katalikų pasaulio leidiniai.

Koenig, H. G. (2012). Religion, Spirituality, and Health: The Research and Clinical Implications. International Scholarly Research Network ISRN Psychiatry, 33. Available at: http://www.hindawi.com/journals/isrn/2012/278730/ (Accessed on 04/07/2016).

Krutulienè, S. (2012). Gyvenimo kokybè: sąvokos apibrěžimas ir santykis su gero gyvenimo terminais. Kultūra ir visuomenè, 3(2), 118-122.

Lietuvos Respublikos Sveikatos sistemos Istatymas. (1994). Available at: http://www3.lrs.lt/pls/inter3/dokpaieska.showdoc 1 ? p _ id =259520\&p_query=\&p_tr2 $=($ Accessed on 04/07/2016).

Milaševičiūtè, V., Pukelienė, V. \& Vilkas, E. (2006). Indeksas gyvenimo kokybei matuoti: analizè, vertinimas ir tyrimas Lietuvos atveju. Organizaciju vadyba: sisteminiai tyrimai, 39, 161-178.

Miler, W. R. \& Thoresen, C. E. (2003). Spirituality, Religion, and Health. American Psychologist, 58(1), 24-35.

Palijanskaitè, R. (2009). Dvasinès sveikatos ir dvasingumo samprata. I sveika gyvensena ir skaidria bütị Vydūno keliu. Klaipèda: Klaipèdos universiteto leidykla.

Popiežius Benediktas XVI. (2009). Enciklika "Caritas in veritate" apie visapusiška žmogaus vystymąsi meilëje ir tiesoje. Kaunas: Katalikų interneto tarnyba.

Popiežius Jonas Paulius II. (1995). Enciklika „Evangelium Vitae“ apie žmogaus gyvybės vertę bei neliečiamumą. Vilnius: Aidai.

Pranckevičienė, A., Žardeckaitè-Matulaitienė, K. \& Gustainienė, L. (2012). Kasdienė dvasingumo raiška ir jos sąsaja su sveikatai palankia gyvensena suaugusiojo amžiuje. Soter, 43(71), 99-111.

Spinter Research (2012) Apklausa: 70 proc. gyventojų mieliau rinktusi ekonomine gerovę, o ne Lietuvos nepriklausomybę. Available at: http://www.spinter.lt/site/lt/vidinis noslide/vidmenu/105/viesosios-nuomonestyrimai/publish/MzM1Ozk7MDsw (Accessed on 30/06/2016).

Staškutė, I. (2014). Su sveikata susijusios gyvenimo kokybès samprata, stebėsenos ir vertinimo metodai bei reikšmė sveikatos politikoje. Sveikatos politika ir valdymas, 1(6), 7-19. Available at: https://www.mruni.eu/upload/iblock/b0f/SPV-14-1-6-01.pdf. (Accessed on 06/06/2016).

Steinmann, R. M. (2010). Spirituality - the fourth dimension of health: health promoting theory and new approaches. 20th IUHPE World conference on health promotion. Available at: http://iuhpe.gesundheitsfoerderung.ch/downloads/en/Programme/PDFs/Steinmann_Ralph.pdf (Accessed on 30/06/2016).

Špidlik, T. (2007). Krikščioniškuju Rytu dvasingumas. Vilnius: Dialogo kultūros institutas. 
DE DE GRUYTER

.

DOI: $10.1515 /$ arhss-2016-0002

Applied Research In Health And Social Sciences: Interface And Interaction, Vol. 13, No. 1, 2016

Šveikauskas, V. (2008). Sveikatos edukologija. Kaunas: Kauno medicinos universiteto leidykla.

Valiulienè, Ž. (2013). Onkologinėmis ir širdies ligomis sergančiuju paliatyviuju pacientu sveikatos sutrikimai ir ju sasajos su dvasingumu. Daktaro disertacija. Kaunas: Lietuvos sveikatos mokslų universitetas.

World Health Organization (1948). WHO definition of Health. Available at:

http://www.who.int/about/definition/en/print.html (Accessed on 04/07/2016). 